\title{
PENERAPAN MODEL PEMBELAJARAN LEARNING CYCLE 5 FASE PADA PEMBELAJARAN IPA UNTUK MENINGKATKAN KUALITAS PROSES DAN HASIL BELAJAR
}

\author{
Budi Santoso \\ SD Negeri 98 Rejang Lebong \\ santoso_budi@gmail.com
}

\begin{abstract}
ABSTRAK
Penelitian ini bertujuan untuk: 1) meningkatkan kualitas proses pembelajaran IPA kelas V SDN 98 Rejang Lebong dengan menerapkan model pembelajaran Learning Cycle 5 Fase; 2) meningkatkan hasil belajar siswa pada pembelajaran IPA kelas V SDN 98 Rejang Lebong dengan menerapkan model pembelajaran Learning Cycle 5 Fase. Penelitian Tindakan Kelas (PTK) ini terdiri dari 2 siklus. Tahapan disetiap siklus terdiri atas tahap perencanaan, pelaksanaan, pengamatan/observasi, dan refleksi. Subjek penelitiannya adalah siswa kelas V SDN 98 Rejang Lebong pada tahun pelajaran 2017/2018. Pengumpulan data dilakukan melalui lembar observasi dan lembar tes. Tes digunakan untuk mengetahui tingkat keberhasilan siswa pada proses pembelajaran, diperoleh bahwa pada siklus I hasil belajar siswa diperoleh rata-rata 6,75 dan persentase ketuntasan belajar klasikal 50\% .Pada siklus II tidak terdapat lagi kelemahankelemahan yang terjadi pada siklus I. Hasil belajar pada siklus II diperoleh ratarata 8,21 dengan persentase ketuntasan belajar klasikal 87,5\%. Hal ini memenuhi keriteria ketuntasan, yaitu $85 \%$ siswa memperoleh nilai $\geq 7,0$ dan proses pembelajaran dikatakan tuntas secara individu apabila siswa memperoleh nilai $\geq 7$. Dapat disimpulkan penerapan model pembelajaran Learning cycle 5 fase pada pembelajaran IPA dapat Meningkatkan Kualitas Proses dan Hasil Belajar Siswa
\end{abstract}

Kata Kunci: Learning cycle 5, Pembelajaran IPA, Hasil Belajar.

\section{ABSTRACT}

This study aims to: 1) improve the quality of the fifth grade science learning process at SDN 98 Rejang Lebong by applying the 5 Phase Learning Cycle learning model; 2) improve student learning outcomes in fifth grade science learning at SDN 98 Rejang Lebong by applying the 5 Phase Learning Cycle learning model. Classroom Action Research (CAR) consists of 2 cycles. Stages in each cycle consist of stages of planning, implementation, observation I observation, and reflection. The research subjects were fifth grade students of SDN 98 Rejang Lebong in the 2017/2018 school year. Data collection is done through observation sheets and test sheets. The test is used to determine the level of success of students in the learning process, obtained that in the first cycle student learning outcomes obtained an average of 6.75 and the percentage of classical learning completeness 50\%. In cycle II there were no weaknesses that occurred in the first cycle. Results learning in the second cycle obtained an average of 8.21 with a percentage of classical learning completeness of $87.5 \%$. 
This fulfills the completeness criteria, which is $85 \%$ of students get a value of , 07.0 and the learning process is said to be completed individually if students get a value of $\geq 7$. It can be concluded that the application of the learning model 5 phase learning cycle in science learning can improve the quality of the process and student learning outcomes

Keywords: Learning cycle 5, Science Learning, Learning Outcomes.

\section{PENDAHULUAN}

Pendidikan merupakan salah satu aspek yang menentukan masa depan bangsa. Untuk itu pendidikan selalu menjadi prioritas penting dalam pembangunan nasional. Dalam mewujudkan pembangunan nasional dibidang ilmu pengetahuan dan pendidikan selalu dituntut peningkatan dan penyempurnaan dalam mutu pendidikan yang disesuaikan dengan perkembangan ilmu pengetahuan dan teknologi, perkembangan masyarakat dan kebutuhan proses pembangunan itu sendiri. Dalam KTSP SD (2006) salah satu program pembelajaran adalah IPA yang merupakan hasil kegiatan manusia berupa pengetahuan, gagasan, dan konsep-konsep yang terorganisir tentang alam sekitar yang diperoleh dari pengalaman, melalui serangkaian proses ilmiah antara lain penyelidikan, penyusunan dan pengujian gagasan. Pembelajaran IPA SD kelas rendah diberikan secara terpadu dengan pembelajaran lain, sedangkan di kelas tinggi pembelajaran diberikan secara terpisah.

Dengan karakteristik siswa yang seperti ini, guru dituntut untuk dapat mengemas perencanaan dan pengalaman pembelajaran yang akan diberikan kepada siswa dengan baik, menyampaikan hal-hal yang ada di lingkungan sekitar kehidupan siswa sehari-hari, sehingga kompetensi yang dipelajari tidak abstrak dan lebih bermakna bagi siswa. Selain itu, siswa hendaknya diberi kesempatan untuk pro aktif dan mendapatkan pengalaman langsung baik secara individual maupun dalam kelompok.

Peneliti memilih SDN 98 Rejang Lebong untuk melaksanakan penelitian ini dikarenakan berdasarkan hasil kegiatan pembelajaran belum maksimal Pembelajaran masih menggunakan model pembelajaran konvensional yang biasanya berpusat pada guru. Pembelajaran lebih menekankan pada penguasaan sejumlah fakta dan konsep, dan kurang memfasilitasi siswa untuk mencapai kualitas proses dan hasil belajar yang comprehensive. Pembelajaran kurang memfasilitasi siswa mengkontruksi pengetahuan dengan hal-hal yang sering ditemui dalam kehidupan sehari-hari siswa.

Melihat permasalahan di atas, salah satu solusi yang dapat ditempuh yakni menggeser paradigma pembelajaran dari tradisi behavioristik ke arah tradisi konstruktivistik (Winarni, 2009). Salah satu model pembelajaran yang konstruktivistik, yaitu dengan menggunakan model pembelajaran Learning Cycle 5 Fase (LC 5E). Model pembelajaran Learning Cycle adalah pengembangan pembelajaran konstruktivistik yang berpusat pada siswa (student centered). Model 
pembelajaran ini terdiri dari 5 tahap yaitu, (1) pelibatan (engage), (2) penyelidikan (explore), (3) penjelasan (explain), (4) pengkaitan (elaborate), dan (5) penilaian (evaluate). Model pembelajaran Learning Cycle merupakan salah satu model pembelajaran yang memberikan kesempatan kepada siswa untuk mengoptimalkan cara belajar dan mengembangkan daya nalar siswa. Berdasarkan latar belakang masalah yang telah diuraikan, maka peneliti tertarik untuk menerapkan model pembelajaran Learning Cycle 5 Fase untuk meningkatkan poses dan hasil belajar pada pembelajaran IPA kelas V SDN 98 Rejang Lebong

\section{METODE PENELITIAN}

Penelitian tindakan ini adalah penelitian tindakan kelas (Classroom Action Research), yaitu penelitian yang dilakukan oleh guru di dalam kelas atau di sekolah tempat ia mengajar dengan penekankan ada penyempurnaan atau peningkatan proses dan praksis pembelajaran (Arikunto, 2006). Penelitian ini menggunakan rancangan penelitian tindakan (Classroom Action Research), secara garis besar terdapat empat tahapan yang lazim dilalui dalam penelitian tindakan kelas yaitu (1) perencanaan, (2) pelaksanaan, (3) pengamatan, dan (4) refleksi (Arikunto, 2008).

Subjek penelitian ini yaitu guru dan siswa kelas V SDN 98 Rejang Lebong, yang berjumlah 16 orang dengan jumlah laki-laki sebanyak 5 orang dan jumlah perempuan sebanyak 11 orang pada tahun ajaran 2018/2019

Pengumpulan data dalam penelitian ini dilakukan dalam beberapa metode, diantaranya adalah sebagai berikut: 1) wawancara, menurut Sudjana (2006) wawancara merupakan alat yang digunakan untuk menilai hasil dan proses pembelajaran. Ada dua jenis wawancara, yakni wawancara berstruktur dan wawancara bebas (tak berstruktur). Wawancara ini digunakan untuk mengetahui data awal tentang sistem pembelajaran, model pembelajaran yang telah digunakan di SDN 98 Rejang Lebong, keadaaan siswa dan kondisi belajar siswa di Kelas V; 2) tes prestasi, menurut Asmawi (2007) tes adalah alat untuk mengumpulkan informasi tentang ketercapaian tujuan pendidikan atau tujuan pembelajaran. Dalam penelitian ini, peneliti mengunakan tes prestasi. Menurut Arikunto (2006) tes prestasi (achievenent) adalah tes yang di pergunakan untuk mengukur pencapaian seseorang setelah mempelajari sesuatu. Tes ini diberikan kepada anak Kelas V SDN 98 Rejang Lebong dengan tujuan untuk mengukur kemampuan dasar dan pencapaian atau hasil belajar. Tes diberikan setelah anak mempelajari materi yang akan diteskan terlebih dahulu; 3) pengamatan (Observasi), pengamatan (Observation) adalah metode pengumpulan data dimana peneliti mencatat informasi sebagaimana yang mereka amati selama penelitian. Untuk penelitian ini peneliti menggunakan observasi terstuktur. Observasi ini dilakukan terhadap guru dan siswa Kelas V SDN 98 Rejang Lebong dengan tujuan untuk mengetahui atau melihat bagaimana aktivitas guru dan siswa selama kegiatan pembelajaran. Observasi terstruktur menggunakan instrumen observasi yang 
terstruktur dan siap pakai, sehingga pengamat hanya tinggal melingkari atau membubuhkan tanda $(\sqrt{ })$ pada tempat yang disediakan (Wardani, 2007); 4) dokumentasi, dokumentasi (dalam http://senidokumentasi.com ) diartikan sebagai kumpulan catatan hasil kerja. Kita mengenal berbagai bentuk dokumentasi. Data dokumentasi yang diambil dalam penelitian ini adalah data tentang hasil belajar siswa yang berupa rata-rata nilai siswa Kelas V SDN 98 Rejang Lebong.

Instrumen penelitian yang diperlukan dalam penelitian ini adalah: 1) lembar tes tertulis, lembar tes tertulis ini berupa post test, yaitu tes yang diberikan setelah proses belajar mengajar berlangsung. Menurut Arikunto (2006) tujuan pemberian tes ini adalah untuk mengukur kemampuan dasar dan pencapaian atau prestasi; 2) lembar observasi, lembar observasi adalah metode pengumpulan data dimana observer mencatat informasi sebagaimana yang disaksikan selama penelitian.

Keberhasilan penelitian ini apabila: 1) Kkualitas hasil belajar IPA siswa dapat ditingkatkan menjadi baik (minimal nilai 70); 2) jumlah siswa yang mendapat nilai $70 \mathrm{ke}$ atas pada pembelajaran IPA dengan menerapkan model pembelajaran Learning Cycle 5 Fase mencapai minimal 75\%; 3) masing-masing kelompok dapat mengerjakan $75 \%$ dari indikator yang ingin dicapai (Depdiknas, 2007); 4) kualitas proses pembelajaran IPA melalui model pembelajaran Learning Cycle 5 Fase di Kelas V SDN 98 Rejang Lebong oleh guru (peneliti) dikatakan baik apabila rata-rata skor aktivitas guru berada pada rentang 26-41; 5) kualitas proses pembelajaran IPA dengan model pembelajaran Learning Cycle 5 Fase pada siswa Kelas V SDN 117 Rejang Lebong dikatakan baik apabila rata-rata skor aktivitas siswa berada pada rentang 26-41.

\section{HASIL PENELITIAN}

Pada pelaksanaan siklus I dilaksanakan observasi terhadap proses pembelajaran yang sedang berlangsung dengan menggunakan lembar observasi yang telah dibuat. Selama pelaksanaan pembelajaran dilakukan observasi oleh dua orang pengamat oleh guru SDN 98 Rejang Lebong. Pada lembar observasi guru yang dilakukan oleh dua orang pengamat yaitu pengamat 1 dan pengamat 2 dengan perolehan skor 27,34. Pada lembar observasi siswa yang dilakukan oleh dua orang pengamat yaitu pengamat 1 dan pengamat 2 dengan perolehan skor 27,5

Berdasarkan hasil tes kemudian dianalisis dengan kriteria persentase ketuntasan belajar klasikal siswa. Dari analisis hasil belajar siklus I diperoleh nilai rata-rata 6,75 dan ketuntasan belajar secara klasikal $50 \%$ termasuk dalam kriteria sedang. Hasil menunjukkan bahwa hasil belajar pada siklus I ini belum bisa dikategorikan tuntas karena dari 8 orang siswa yang mendapat nilai 70 ke atas sebanyak 8 orang atau $50 \%$.

Pada lembar observasi guru siklus II yang dilakukan oleh dua orang pengamat yaitu pengamat 1 dan pengamat 2 dengan perolehan skor 34,5. Pada 
lembar observasi siswa yang dilakukan oleh dua orang pengamat yang dilakukan oleh pengamat 1 dan pengamat 2 dengan perolehan nilai 29 yang merupakan gambaran dari aktivitas yang dilakukan oleh siswa selama proses pembelajaran model pembelajaran Learning Cycle 5 fase pada siklus II.

Berdasarkan hasil tes menunjukkan bahwa aktivitas siswa pada proses pembelajaran rata-rata skor yang diperoleh dari dua orang pengamat sebesar 34,5. Nilai ini termasuk dalam kategori sangat baik.

\section{PEMBAHASAN}

Berdasarkan ketentuan Depdiknas(2007) bahwa kriteria ketuntasan belajar untuk masing-masing indikator $75 \%$ dan untuk mata pelajaran IPA indikator ketuntasan belajar secara klasikal, apabila siswa memperoleh nilai 70 ke atas sebanyak 75\% (Depdiknas, 2007). Pada siklus I diperoleh nilai rata-rata 6,75 dan ketuntasan belajar secara klasikal $50 \%$ termasuk dalam kriteria sedang. Hasil menunjukkan bahwa hasil belajar pada siklus I ini belum bisa dikategorikan tuntas karena dari 8 orang siswa yang mendapat nilai 70 ke atas sebanyak 8 orang atau $50 \%$. Ketidaktuntasan hasil belajar ini dikarenakan proses pembelajaran IPA dengan menerapkan model pembelajaran Learning Cycle 5 fase belum terlaksanakan dengan baik karena adanya kekurangan dan kelemahan pada pelaksanaan tindakan, baik aktivitas guru maupun aktivitas siswa. Dengan demikian memerlukan refleksi untuk proses kegiatan pembelajaran selanjutnya.

Pada siklus II, berdasarkan hasil tes menunjukkan bahwa aktivitas siswa pada proses pembelajaran rata-rata skor yang diperoleh dari dua orang pengamat sebesar 34,5. Nilai ini termasuk dalam kategori sangat baik. Penerapan model pembelajaran Learning Cycle 5 fase pada siklus II ini telah mengalami peningkatan dari proses pembelajaran pada siklus I. Hampir $80 \%$ siswa aktif dan terlibat dalam kerja kelompok dan sudah mulai terbiasa menemukan dan mengkonstruksikan pengetahuan sendiri melalui 5 fase pembelajaran.

Dari analisis hasil belajar siklus II diperoleh nilai rata-rata 8,21 dan ketuntasan belajar secara klasikal 87,5 \% termasuk dalam kriteria sangat tinggi. Hasil menunjukkan bahwa hasil belajar pada siklus II mengalami peningkatan dilihat dari peningkatan nilai rata-rata kelas 8,21 dan dari 16 orang siswa yang mendapat nilai 70 ke atas sebanyak 14 orang yaitu 87,5\%. Berdasarkan ketentuan Depdiknas (2007) bahwa kriteria ketuntasan belajar untuk masingmasing indikator $75 \%$ dan untuk mata pelajaran IPA indikator ketuntasan belajar secara klasikal, apabila siswa memperoleh nilai 70 ke atas sebanyak $75 \%$ (Depdiknas, 2007). Hal ini berarti bahwa pembelajaran IPA di Kelas V sudah dikatakan tuntas.

Dalam kegiatan model pembelajaran Learning Cycle 5 fase akan menciptakan aktivitas bertanya yang berguna untuk menggali informasi yang dimiliki siswa, mengecek pemahaman, dan membangkitkan respon siswa. Bertanya dalam pembelajaran dipandang sebagai kegiatan guru untuk mendorong, 
membimbing, dan menilai kemampuan berpikir siswa. Uraian di atas menjelaskan bahwa adanya peningkatan aktivitas dan hasil belajar dari siklus I sampai siklus II setelah diterapkannya pembelajaran melalui model pembelajaran Learning Cycle 5 fase.

\section{SIMPULAN}

Berdasarkan hasil penelitian dapat dismpulkan pelaksanaan proses pembelajaran dengan menerapkan model pembelajaran Learning Cycle 5 fase dapat meningkatkan kualitas proses dan hasil belajar pada pembelajaran IPA di SD Negeri 98 Rejang Lebong.

\section{DAFTAR PUSTAKA}

Arikunto, S. (2006). Prosedur Penelitian Suatu Pendekatan Praktik. Jakarta : PT Rineka Cipta.

Depdiknas. (2006). Kurikulum KTSP. Jakarta : Depdiknas

Sudjana, N. (2006). Penilaian Hasil Proses Belajar Mengajar. Bandung : PT Remaja Rosda Karya.

Wardani, I. G. A. K. (2007). Penelitian Tindakan Kelas. Jakarta : Universitas Terbuka

Winarni, E. W. (2009). Mengajar IPA Secara Bermakna. Bengkulu : UNIB PRESS

Zainul, A. (2007). Tes dan Asesmen di SD. Jakarta : Universitas Terbuka 